\title{
STRATEGIC PLANNING DISTRESSED AREAS IN KERMAN (CASE STUDY: NEIGHBORHOOD KHAJEH KHEZR KERMAN)
}

\author{
Mr.Amirali Mohseni \\ M.A Student in Urban Planning, Kerman Branch, Islamic Azad University, Kerman, Iran \\ rmohseni89@gmail.com \\ Mr.Alireza Behrad \\ M.A Student in Urban Planning, Kerman Branch, Islamic Azad University, Kerman, Iran \\ rezaali.rad@gmail.com
}

\begin{abstract}
The historic Urban of Khaje-KhezrInkerman cannot Serve well to its habitants anymore due to Fatigues of Its structure and also lack of infrastructures. In order to address those problems, This area is losing its population because people which usually live there for long years are leaving there to higher levels areas of city to receive better services but the problem is people which have less annual income are getting replaced by them and it could be the beginning of some new issues such as social and culture fluctuation in that urban which will be increased by time. We cannot find cultural congruity at the named area anymore and vicinity order between the residences is completely vanished due to different types of people there. Movement of pure and main habitants to other areas brought forgetfulness to valuables values, good memories, identity and sense of being belong to this area and when such a things get forget they will cause damage to the building and make them abandoned and just ruined which could be a factor of social harms. In this paper required informations gathered by asking the locals, get visualized by shooting the urban, field view and also providing detailed maps of it and for analyzing the Data SWOT Techniquehas been used.
\end{abstract}

Keywords: Neighborhood Khajeh Khezr, social and physical stability, sustainability strategies

\section{INTRODUCTION}

Stability in historic urbans can be defined with different factors such as stability in structure of residence complexes, stability in actions, stability in functions and cultural issues. Finding the relation between these factors will show us how and why this stability faced with the problems and became unstable and how we can solve this?

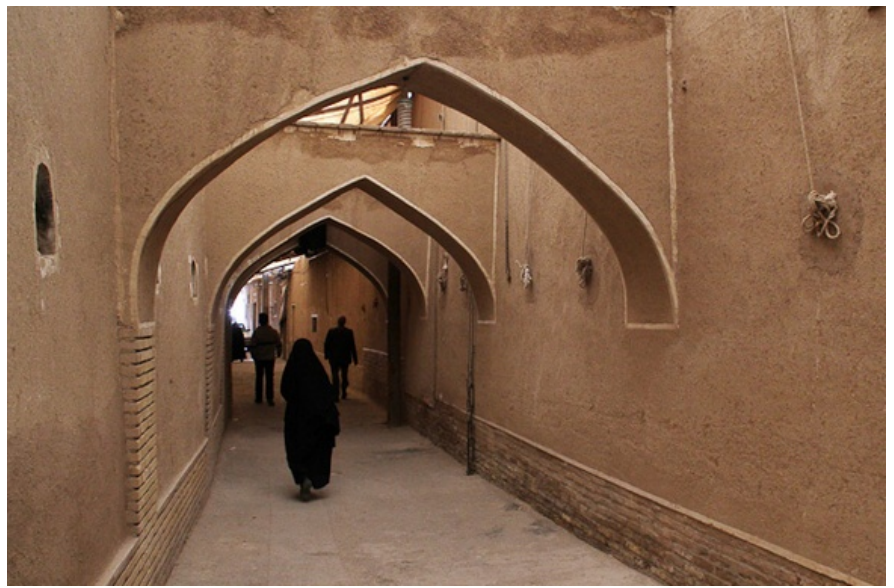

In the historic urbans these two parameters are very important for satisfactory of the habitants: 1empowerment of the structure 2-activities. By spending time and money on these two we can bring 
back lots of thing to the balance such as sense of being belong to the area which will make people take care of the area again.

An area can be stable by society and structure when it brings happiness and satisfactory to its habitants by living there and don't feel any inconvenience by the neighbors or the area itself. In this case by the pass of time habitants will be eager to do more social interaction with the neighbors and also it will brings more and more activities in the area which will head people to stay there and feel better by staying there. This could be the main reason of stability of an area.

This paper is a functional-development one and it will complete with descriptive- analytic methods. This paper has been completed with repetitive field views, shooting, and providing required maps and finally it was followed by some questionnaire of the people who are living and lived there then for giving the solutions SWOT technique has been used.

This technique is a useful analytic method which will detect any strength, weakness, opportunity and threats in an organized form and show the correct strategies based on the current status of area. By this method there areattempts for analyze of inner and outside status of area and based on the result fine solutions for stability of an historic urban will be determine. Extracted opportunities and threats are main challenges which will be in the future planning of the area. There was a statistical population which been questioned about this area's social, cultural, and structural issues and they were habitants of this area. 100 person of the habitants have been selected and asked.

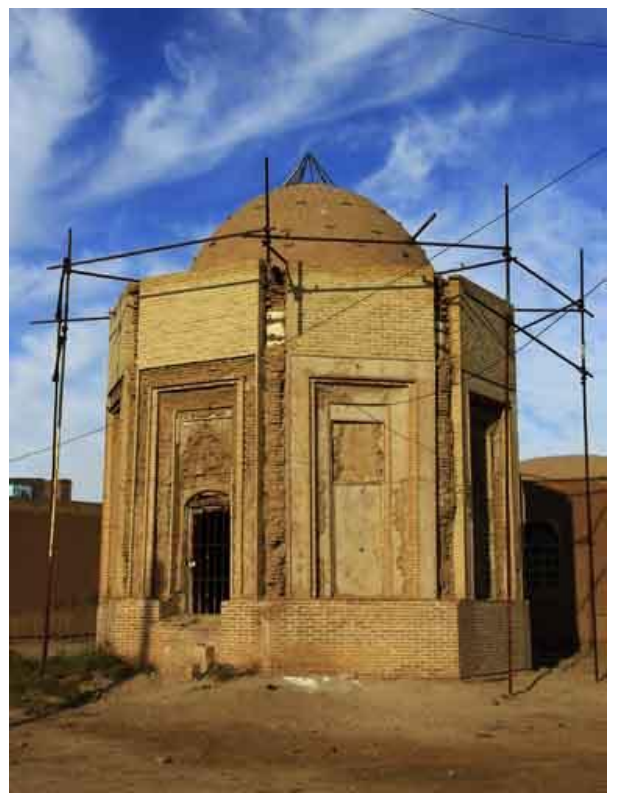

\section{RESEARCH THEORY}

Neighborhood of Khaje-khezr has habitants which they are the same in parameters of social, economy and demography but the word of society here means mutual association which it is a part of social solidarity and it itself brings uniformity to the customs. So society is some kind of social solidarity which cause sense of being belong to somewhere and it may has the meaning of vicinity or may not.

By the meaning of social stability some of the researchers pointed 4 main elements such as: 1-social justice 2-social solidarity 3-interaction 4-safety

Here parameters such as equal opportunity with progress for everyone, living with cooperation, subsistence and safety of human residence against natural disasters are base evaluating of social stability. 


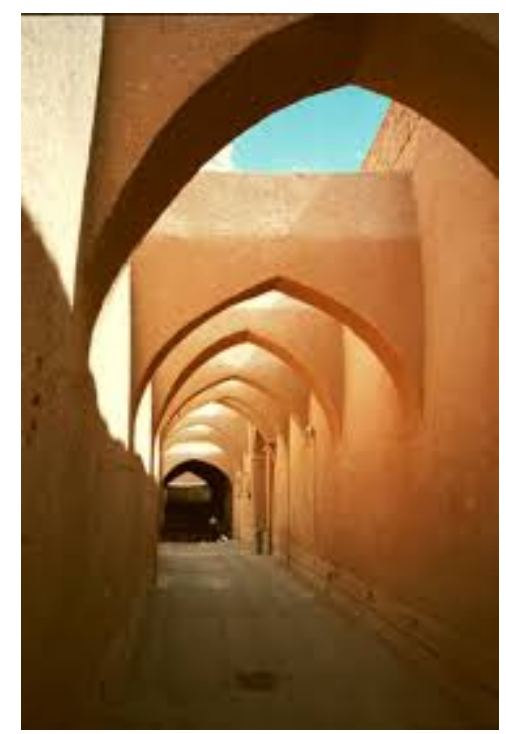

\section{KHAJE-KHEZR NEIGHBORHOOD}

This neighborhood is one of the oldest areas of Kerman which based on some books its history backs to seventh century in Islamic calendar. Some of the researchers such as Dr.BastaniParizi believed that it has longer history. This area has linked from north to Abouhamed Street, Ghobesabz and BaghLeleh from East, Palestine street from west and from south it would be linked with Shariati Street. At the beginning its name was Tork Abad and it must be mentioned why it was Tork Abad? At the first years of seventh century after defeat of Seljuq and Kharazmian Dynasty one of the leaders named BoraghHajeb was heading to India from kerman. But when he found the situation proper at 619 of Islamic calendar he founded the Qara-KitaiInkerman. One of the main building which he established in this area was Big Seminary which years after he got buried in that place. Rulers after him such as Ghatlegh-torkan ruled for the next 26 years and because she liked art too ordered to complete the building of seminary. Probably nowadays Khaje-Khezr Mosque was a part of that building. Finally due to change of the governments that building demolished and turned into the residential buildings.

Checking the current status of Social, Economy, Structure and culture of the area:

Main habitants as told before leave the area to other better areas of city and they have replaced with some families which have no sense of belong to this area. Although the past habitant still try back to the neighbor at the specific times of the year to pay a visit but they can't live there due to the problems which has mentioned before.

Based on the questionnaires, two of the main cultural problem of this area was Addiction and lack of safety which can be considered as social harms. The other problems which habitants mentioned was old and ruined buildings in the area which some of them are still in use for living and they are not safe at all. The other one is lack of any amusing place in the area.

\section{DATA ANALYS}

For the analysis of physical-social sustainability strategies in the historic neighborhood of Khajeh Khezr techniques «SWOT» is used. 


\begin{tabular}{|c|c|c|c|}
\hline 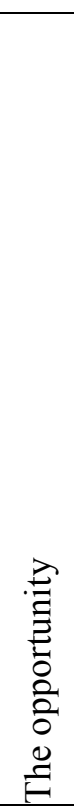 & $\begin{array}{l}\text {-There Service functions within the } \\
\text { surrounding tissue with the role of } \\
\text { regional and trans-regional } \\
\text { - The role of NGO and other non- } \\
\text { governmental organizations in the } \\
\text { management and town planning } \\
\text { - According to the social values of } \\
\text { the society in the hierarchy of } \\
\text { values } \\
\text { - Financial support through } \\
\text { religious beliefs (devotion, charity, } \\
\text { etc.) } \\
\text { - The use of economic power to } \\
\text { regulate tissue residents in the } \\
\text { neighborhood } \\
\text { - Ability to participate in organized } \\
\text { tissue owners through financial and } \\
\text { credit lending }\end{array}$ & $\begin{array}{l}\text { - There Religious base as a consolidating } \\
\text { sector and community involvement in } \\
\text { neighborhood } \\
\text {-Lackof inappropriate uses within the } \\
\text { context } \\
\text { - Geographical position of texture } \\
\text { - The relative number of outreach } \\
\text { initiatives related to retrofitting old } \\
\text { buildings } \\
\text { - A little distance between the CBD and } \\
\text { residential units in the context of } \\
\text { neighborhood services and are willing to } \\
\text { walk for access to the core } \\
\text { - Relatively the same height and low } \\
\text { building blocks for tissue } \\
\text { - Green spaces within the tissue }\end{array}$ & \\
\hline $\begin{array}{l}\overrightarrow{\overparen{J}} \\
\stackrel{\Xi}{\Xi} \\
\stackrel{\Xi}{E}\end{array}$ & $\begin{array}{l}\text { - Social problems such as drug } \\
\text { dealing and addiction } \\
\text { - Ambiguity in the rules and } \\
\text { regulations relating to the } \\
\text { organization of urban city view } \\
\text { - Lack of awareness of citizenship } \\
\text { rights. } \\
\text { - Disregard the role and } \\
\text { participation of people in decision- } \\
\text { making } \\
\text { - Multiple decision-making bodies } \\
\text { and the distance between decision- } \\
\text { makers and decision-maker in } \\
\text { matters relating to devices worn out } \\
\text { tissues } \\
\text { - Lack of equitable distribution of } \\
\text { wealth, power and income } \\
\text { - The presence of trans-regional } \\
\text { land surrounding tissue, thereby } \\
\text { attracting crowds of other places in } \\
\text { the neighborhood }\end{array}$ & $\begin{array}{l}\text { - Ignoring the social forces in approved } \\
\text { and implemented in the texture } \\
\text {-Lack of continuous sidewalks and } \\
\text { appropriate in the context of } \\
\text { - Confusion and inappropriate pieces of } \\
\text { urban landscape (in terms of longitudinal } \\
\text { and transverse) due to organic shape } \\
\text { texture } \\
\text { - The existence of criminal behavior and } \\
\text { abnormal tissue in certain areas of } \\
\text { - Much problems in providing relief } \\
\text { services including instant access to } \\
\text { ambulance, fire, police and emergency ... } \\
\text { - The low social status and social Normal } \\
\text { - Empty the texture of the original } \\
\text { inhabitants and the presence of } \\
\text { immigrants, especially in the context of } \\
\text { Afghans }\end{array}$ & \\
\hline
\end{tabular}

Khajeh Khezr community organizing strategies tissue

After studying the factors affecting social stability neighborhoods based on the experiences of other countries and Iran Also check out the background of strategic planning and SWOT of the neighborhood Khajeh Khezr in Iran and the world to achieve the following strategies:

\section{STRATEGIES SO}

1 - grant long-term loans without interest to residents to participate in organizing and strengthening tissue

2 -citizen support policies and taking advantage of the economic and functional neighborhood quality of life with emphasis on tissue regeneration approach

3 -peaceful strengthen the social and biological behavior of residents from other neighborhoods on the principles of value 
The Turkish Online Journal of Design, Art and Communication - TOJDAC July 2016 Special Edition

4- increase interaction between religious institutions and civil society organizations with the aim of creating a foundation for civic participation, so that the planning process be done with people.

5-. leisure and public spaces with community functions in accordance with the criteria set forth in laws and plans for the efficiency and effectiveness of tissue

\section{WO STRATEGIES}

1 -benefit from the facilities for the participation of non-governmental organizations (NGO) and people in the process of preparation, implementation and monitoring of projects related to tissue

2 -managers and urban planners to visual appearance and walk through tissue to create the right plan

3- increase the social status of people weave through engagement in leisure and changes in the attitude of the community towards recreating the tissue through cultural solutions

4 people living in the neighborhood cooperation providing for the deployment of technology and new methods in solving problems of physical, social and economic people living in distressed areas

\section{ST STRATEGIES}

1 -to strengthen the sense of place and social cohesion through common cultural convergence and articulation residents using social damage control

2- to apply rules and strategies and collaborative outreach project in accordance with the facts and their dissemination to the public to reduce environmental damage and human

3- axes walk in centers create a link between neighborhoods and distressed areas

4- raise awareness and civic engagement and public consultation meetings in various religious ceremonies

\section{WT STRATEGIES}

1- regarding the social forces involved in preparing and reviewing the rules and regulations to organize and texture issues requiring institutions and organizations to observe it

2 -utilizes public areas, partnership programs and links to increase spatial interactions neighborhood

3 -equitable distribution of services and wealth planning with an emphasis on justice

4.- institutions and decision-making and the formation of specialized working groups on issues of worn tissue to accelerate the administrative and regulatory

5- load control programs to reduce the harm caused by the use of trans-regional social neighborhood

6 -programs, retrofit and improve the safety of buildings and synthetic environmental disaster

7 -rules of urban development standards in urban design for pedestrian crossings

\section{CONCLUSION}

The main characteristic of the anatomic structures of the space through property regulation and planning systems and Targeted for the variable in space and time that is most important to their social goals (electric effects, 1380).

So in order to achieve development and revival of the historical context and structure of the buildings it just maintaining body tissues, especially the centers, can not alone be considered But rather should 
be considered social activities of this structure to a dynamic tissue and skeletal bring Bahvyt. What is considered less sustainable development plans, and activities are uncoordinated body. Many neighborhoods impaired social relationships, fading sense of belonging and inappropriate Fzabray residents are spending their leisure time. The main reason for this situation changed and the absence of appropriate spaces in neighborhood centers, cultural changes in the type and How to arrange some local tournaments and changes in the type of space they are holding. In order to improve the neighborhood and revive it as it should be Needs and expectations of local residents were planning a priority.

\section{REFERENCES}

electrical effects, Shahindokht (1380), the physical structure of the physical centers, general journal, Issue 33, 11 years.

Soltanzadeh, H. (1390), A Brief History of urbanism in Iran from ancient times to 1355 AD. Proj. Penthouse Publishing, Printing, Tehran.

Soltanzadeh, H. (1370), urban spaces in historical contexts Iran, The Cultural Research Bureau in Tehran.

Sy.jy.barv (1376), sustainable development, the concept of value and operation, translated by Ali Badri,

Geographical Research Quarterly, Issue 44.

Shakuie, H. (1369), urban social geography, social ecology City, Central Office Publication (SID), Tehran. 